\title{
USE OF E-LEARNING IN IMPROVING THE PROVISION OF TEACHING MATERIALS IN THE MICE STUDIES PROGRAM STATE POLYTECHNIC OF MEDAN
}

\author{
Mardhiatul Husna,ST.,M.Cs. \\ Politeknik Negeri Medan \\ Mardhiatul.husna@polmed.ac.id
}

\begin{abstract}
This research aimed to improve the quality of learning by providing teaching materials to students in an easier way, can be accessed at any time by implementing e-learning in MICE Studies Program Department of Business Administration. Generally students understand e-Iearning as a learning method that utilizes the Internet and online computer. So this will facilitate the implementation and utilization of e-Iearning at the Department of Business Administration. This research utilizes a Content Management System (CMS) Moodle as a means to build applications web-based learning, CMS Moodle been already popular used so expect faculty and students can easily use and CMS Moodle is available directly in the web hosting services that can save time installation This research is also expected to motivate the teaching staff be more active in preparing and making teaching materials for the learning process can run better.
\end{abstract}

Keywords: e-Learning, Moodle, internet, Business Administration, MICE

\section{INTRODUCTION}

The development of information technology can improve performance and enable a wide range of activities can be carried out quickly, precisely and accurately, thereby increasing productivity. In addition, the development of information technology has affected many aspects of life, one of which is education.

Information technology has functioned as a supplier of knowledge. The rapid progress of these technologies must be complemented by efforts to improve the quality of education and knowledge. Therefore, the information technology can be used to create skilled human resources and reliably. In achieving these objectives, the use of information technology is determined by the precision of the use of the strategy. Information on education and knowledge can be obtained via the internet, which have long known and have been widely used to improve the quality of education and knowledge in various countries including in Indonesia. With the help of information technology, improving the quality of education and knowledge could be solved with e-learning.

A learning system that utilizes the advantages possessed by the internet, which has been used as a medium for knowledge transfer. A system that gives the freedom of time, place, and not only oriented to the lecturer. The function of the application of e-learning can be as an additional (supplement) or a complement/ support or as a replacement (substitution) conventional learning (Siahaan, 2001).

Although it has been realized e-learning can help improve the quality of education and knowledge, the current utilization has not been fully implemented at the Polytechnic of Medan in general and particularly in the Department of Business Administration. Based on the few things that have been described above, 


\section{PROCEDINGS}

INTERNATIONAL CONFERENCE REVITALIZATION OF VOCATION AL EDUCATION IN FREE TRADE ERA (ICERVED) 2016

it is possible for the Department of Business Administration to begin implementing e-learning as a complement or support system of conventional learning system in the provision of better teaching materials and easily accessed by students.

\section{BASIC THEORY \\ Definition of e-Learning}

E-Learning or electronic learning has been started in the 1970s. There are so many terms used to express opinions or ideas about electronic learning, among other things: Online Educational Delivery Applications (OEDA), Virtual Learning Environments (VLE), Web Learning Environments (WLE), Managed Learning Environments (MLE) and Network Learning Environments (NLE) (Anggoro, 2005). Today, e-learning is emerging in Indonesia. E-learning is electronic learning by utilizing information and communication technology. E-learning actually has a very broad definition, even a portal that provides information on a specific topic can be covered in the scope of e-learning, such as portals ilmukomputer.com. However, the term e-learning is more appropriately addressed in an effort to create a transformation process of teaching and learning at school or college into a digital form that utilize the facilities of information technology, namely the Internet (Anggoro, 2005).

Intemet's role can't be separated from the use of e-learning. According to William, the Internet is "a large collection Of computers in networks that are tied together so that many users can share their vast resources". So the intemet is basically a collection of information available on a computer that can be accessed because the network is available on the computer. This is in accordance with the opinion Kamarga(2002) which essentially emphasizes the use of the Internet in education as the essence of e-learning. Even Onno W. Purbo (2002) explained that the term "e" or stands for electronic e-learning is used as a term for any technology that is used to support the efforts of teaching via Internet electronic technology.

E-learning facilitate interaction between students and learning materials. Similarly, the interaction between students and faculty and among students. Students can share information or opinions on various matters relating to the lessons and other needs for personal development of students. Lecturers can place an online teaching materials that can be downloaded by students and giving assignments to students as well as its collection via email. Interaction can also be made directly between students and professors or fellow students through discussion forums (eg mailing lists, discussion forums).

\section{E-Learning as an Instructional Media}

E-Learning including learning model centered on the learner. With this, the students demanded an independent and responsible for the learning process, because students can learn anywhere, anytime, which is important available tools. E-Learning requires active learners. Through E-Learning, learners can search for and retrieve information or learning materials based syllabus or criteria established teachers or education managers. Learners will have a wealth of information, because students can access information from anywhere related learning materials. Learners can also online discussion with experts in the field, 


\section{PROCEDINGS}

INTERNATIONAL CONFERENCE REVITALIZATION OF VOCATION AL EDUCATION IN FREE TRADE ERA (ICERVED) 2016

via e-mail or chat. Thus, it is clear that active learners in E-Learning is crucial learning outcomes they get. The more active he is, the more knowledge or skills to be acquired, with a system of this kind is expected that the outcome of the learning process with the ELearning will be better, because it demands complete learning (mastery learning) can be met. Learners are also free access to learning materials.

E-Learning instructional materials were designed and professionals will pay attention and use multimedia features. That is, in the learning materials in addition to a text, also can contain images, graphics, animation, simulation, audio, and video. Color selection is good and right will also improve the appearance on the screen. This makes the study materials E-Learning becomes more interesting, memorable, interactive and attractive. This kind of situation allows learners always remember about what was learned. Model development of ICT in education can be carried out in four stages, namely emerging, applying, infusing, and transforming (Majumdar (2005) inside Budi Murtiyasa (2012)). According to Sudirman Siahaan (2004) in Edhy Sutanta (2009), there are at least three functions of E-Learning for learning activities in the classroom (classroom instruction):

a. Supplements (extra). Is said to serve as a supplement if the students have the freedom to choose whether to take advantage of electronic learning material or not. In this case there is no requirement for students to access the material. Even is optional, students who use it will have additional knowledge or insight.

b. Complement. Is said to serve as a complement if programmed electronic learning material to supplement learning materials received by students in the classroom. As a complement programmed electronic means of learning materials to supplement the material enrichment or remedial. Told as enrichment, when the learners can quickly master or understand the subject matter presented during the face-to-face given the opportunity to access the electronic learning material that is Specially developed for them. The goal is that further strengthen the level of mastery of the subject matter that has been received in the classroom. Told as a remedial program, where students who have difficulty understanding the subject matter at the time of face-to-face given the opportunity to take advantage of electronic learning materials that are specifically designed for them. The goal is to make the students more easily understand the subject matter presented in class.

c. Substitution (replacement). Told as a substitute when the B-Learning is done instead of learning activities, for example by using models of learning activities. There are three models to choose from, namely: (1) fully face-to-face (conventional), (2) most face-toface and partly via the internet, or (3) entirely over the internet.

\section{Benefits of e-Learning}

There are so many benefits to be gained from the implementation of e-learning, including:

a. Simplify and increase the time interaction between students with learning materials and interaction between students and faculty and among students.

b. Makes it possible for students to continue to learn even if not physically present in the classroom. Learning to be very flexible because it can be 


\section{PROCEDINGS}

INTERNATIONAL CONFERENCE REVITALIZATION OF VOCATION AL EDUCATION IN FREE TRADE ERA (ICERVED) 2016

adapted to the availability of time students. So that the interaction of learning from anywhere and at anytime.

c. Allowing students and teachers can share information or opinions about the course material so as to optimize the time available for face-to-face on the concentration of the material.

d. Improve the quality and performance of lecturers by developing models that better teaching and learning materials that are easier to understand and studied by students.

e. Reducing the digital divide between lecturers and students with the application of Internet The technology-based systems in an integrated and integrated.

f. Facilitate refinement and storage of learning materials

\section{RESEARCH METHODS}

Types and Sources of Data

Data used in this study are primary data and secondary data. Primary data were obtained through a questionnaire distributed to respondents students and lecturers in the Department of Business Administration, while secondary data obtained through the study of literature.

\section{stages Research}

In conducting this research using the method of Software Development Life Cycle (SDLC) which consists of several phases of activity as follows:

a. Study of literature, ie literature search of information about the basic theory that supports the research, studying the literature on e-learning.

b. The collection of data and information from the Department, the Student and Lecturer of Business Administration

c. Making the e-learning system consists of several stages, namely:

- $\quad$ Rent Hosting and Domain Names

- Install e-learning to the web server

- Customize e-learning fit the needs of the Department of Business Administration

- Upload the teaching materials MICE Studies Program Department of Commerce Administration

\section{d. Implementation}

At this stage, the socialization of e-learning in students and lecturers.

e. testing

At this stage of the e-learning system that has been implemented will be testing whether the system is run in accordance with the purpose.

\section{RESULTS AND DISCUSSION}

\section{Preparing Hosting and Domain Name}

To be able to online the website must first be prepared hosting and domain so that websites built can be accessed from the Internet, hosting is the internet service that provides resources sewers for rent that allow organizations or individuals to put information on the Internet in the form of HTTP, FTP, DNS, while eMAIL or domain name is a unique name assigned to identify the name of the server computer as a web server or email server on a computer network or the 


\section{PROCEDINGS}

INTERNATIONAL CONFERENCE REVITALIZATION OF VOCATION AL EDUCATION IN FREE TRADE ERA (ICERVED) 2016

Internet. Domain name serves to facilitate users on the Internet when access to the server, as well as used to remember the name of the server that visited without having to know complicated series of numbers known as IP addresses. The domain name is also known as a union of a website such as for example "polmed.ac.id". The domain name is sometimes also referred to as the URL, or website address.

Hosting and domain can be obtained by hiring a hosting service provider who will also provide maintenance services domains, domains with .com easiest class in the submission because it does not require a lot of documents, while for class id domain is more difficult because it requires some supporting documents especially for sch.id or ac.id for the maintenance of the Indonesian special domain can be done by opening www.pandi.org site.

\section{Installing Moodle from CPanel}

In the paid hosting services will put up a service control panel to manage all the user needs the owner of the site, which is better known as Cpanel, on Cpanel user normally will be given the facility of Softaculous auto installer.

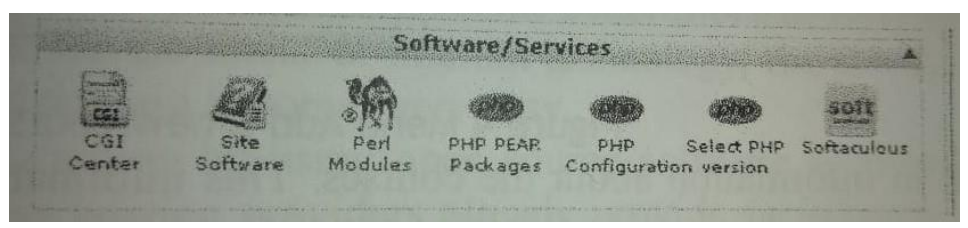

Figure 1 Softaculous menu in Cpanel

So as to be able to install CMS Moodle with a much easier and more practical because it has been given the facility to it, so as to be able to install Moodle CMS are no longer required knowledge of web programming, SQL and File transfer Protocol.

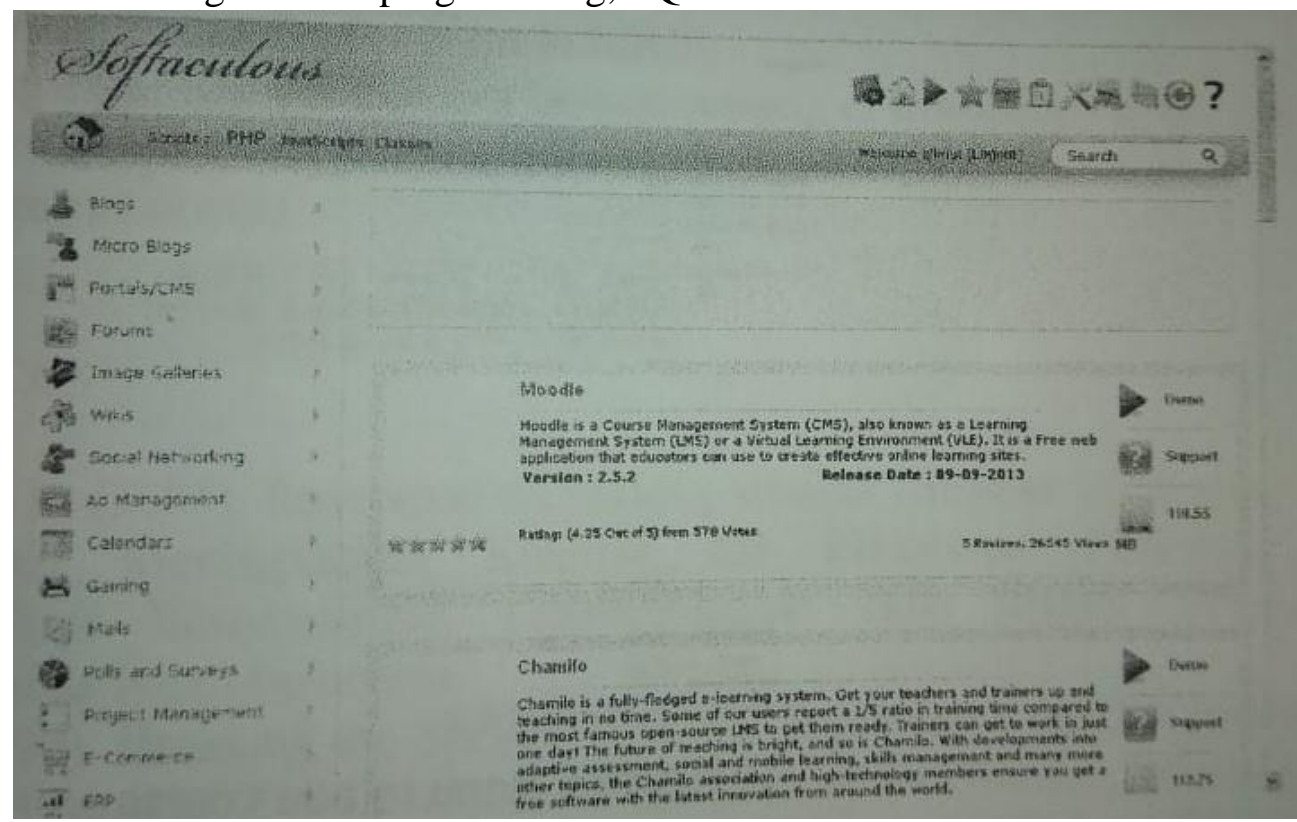

Figure 2 Menu Install Moodle of Softaculous

\section{Moodle Course Management}

On Moodle, which can manage course there is only a user with a role as a teacher, and of course the admin can do anything. Although the user with course creator role can create a course, but the user can not modify the course he created when he was not teaching at the course (not a teacher). 


\section{PROCEDINGS}

INTERNATIONAL CONFERENCE REVITALIZATION OF VOCATION AL EDUCATION IN FREE TRADE ERA (ICERVED) 2016

\section{Adding Course}

To add a new courses, click the "Course" in Administration section

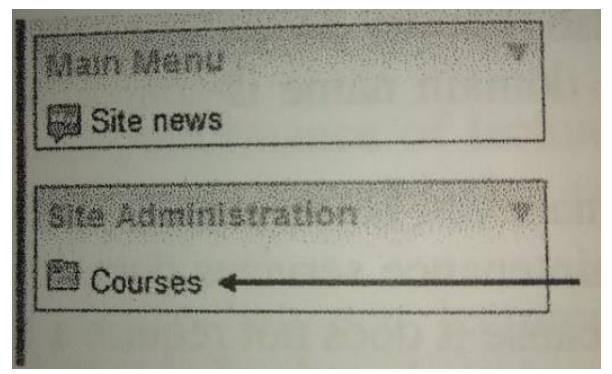

Figure 3 Menu adds Courses

Click the "Add I edit course".

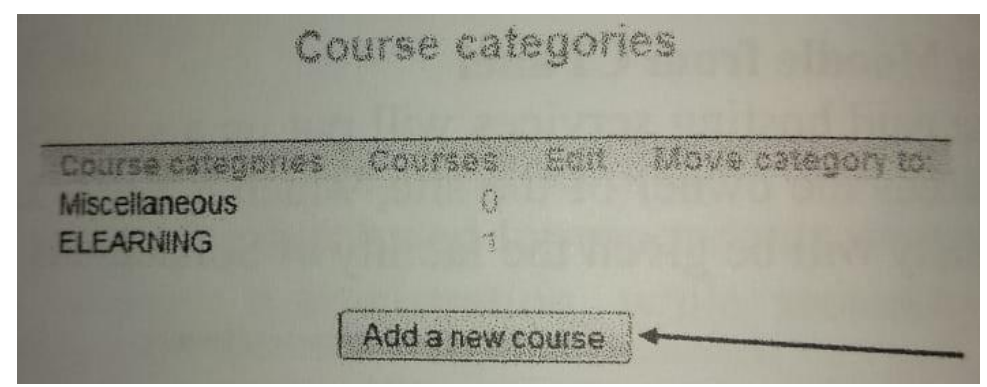

Figure 4 Menu Add a new course

Then fill in information about the courses. This information can be edited again later.

For the stuffing format, there are some options

1. Format Week / Weekly Format: lectures are arranged per week.

2. Format Topic / Topic Format: lectures arranged each topic.

3. Format Social / Social Format: only shaped the discussion

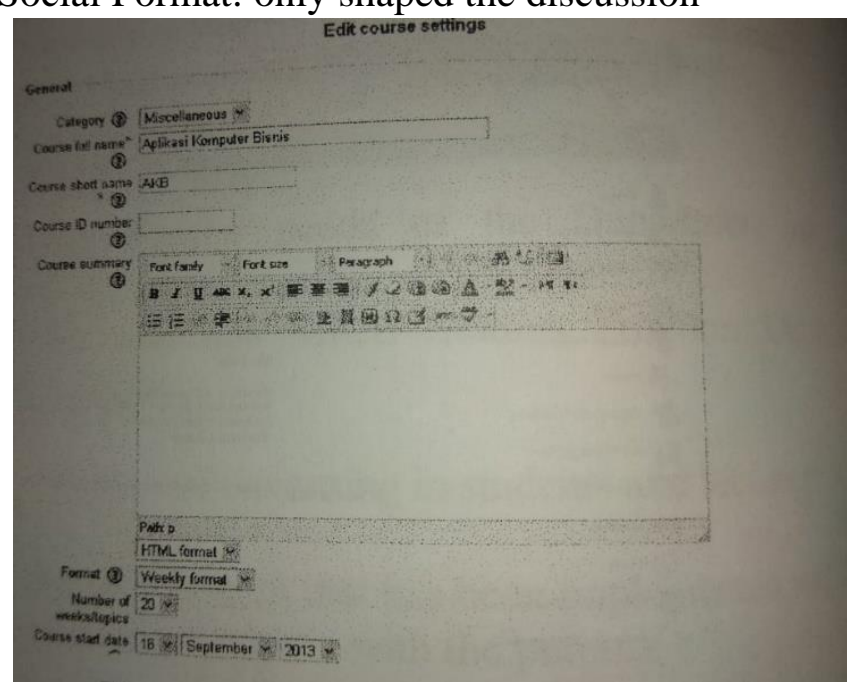

Figure 5 Menu to add course

To restrict access, lecturers can add a key entry (like a password). If the key entry is filled, then the first time to follow the course, students must enter this key (only needed once). This key can be given to students in private lecturers by email or posted on the front of the class. Whereas if guest access is allowed, people who do not have accounts (guest) can go in and see course material. 


\section{PROCEDINGS}

INTERNATIONAL CONFERENCE REVITALIZATION OF VOCATION AL EDUCATION IN FREE TRADE ERA (ICERVED) 2016

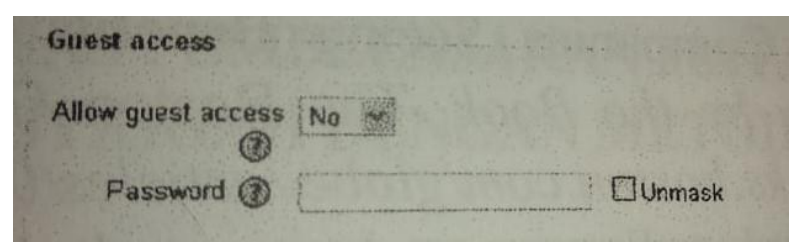

Figure 6 Menu to allow guest users to see material

When Finished, click the "Save changes" further lecturers have started to fill up material. To re-edit the configuration of courses (eg set number of topics). Use the "Settings" section Administration.

\section{Inserting Content}

There are two ways to enter the material into Moodle. First by typing directly through the site. 130th with upload word, powerpoint, pdf. Previous Go to change mode, the Administration menu select "Tum editing on". On Moodle also equipped with an online exam.

\section{CONCLUSION}

From the research results can be drawn some conclusions as follows:

- In line with the development of internet technology, the process for obtaining the hosting and domain becomes very easy.

- build an E-Learning by using open source software such as Moodle is not difficult because hosting providers already provide facilities to install quickly with facilities Softaculous on Cpanel, to build an E-Learning is almost not needed anymore knowledge about programming Web, Database, and File transfer Protocol so that anyone can build an E-Learning.

- Not exploited E-Learning in the learning process or as a medium for supporting the provision of teaching materials in particular the Department of Business Administration Program in MICE.

- E-Learning exploited yet due to a lack of training or knowledge in the use of ELearning in the learning process and not optimum support E-Learning facilities such as Internet access.

\section{REFERENCES}

Anggoro, W. B. (2005). Penerapan e-Learning sebagai Langkah Universitas Islam Indonesia Meningkatkan Kualitas dan Efektivitas Penyelenggaraan Pendidikan Konvensional. Lomba Karya Tulis Ilmiah. Yogyakarta: Universitas Islam Indonesia

Beam, P. (1997). Breaking the Sprinter's Wrist: Achieving Cost-Effectiveness in Online Learning. The International symposium on Distance Education and Open Learning. Bali, Indonesia: MONE Indonesia, IDLN, SEAMOLEC, ICDE, UNDP dan UNESCO.

Bullen, M. (2001). e-Learning and the Internationalization Education. Malaysian Journal of Educational Technology. Vol. 1, No. 1, p. 37-46.

Kamarga, H. (2002). Belajar Sejarah melalui e-Learm'ng: Alternatif Mengakses Sumber Informasi Kesejarahan. Jakarta: Inti Media. 
PROCEDINGS

INTERNATIONAL CONFERENCE REVITALIZATION OF VOCATION AL EDUCATION IN FREE TRADE ERA (ICERVED) 2016

Lewis, D. E. (2002).. More Companies Seeing Benefits of E-Leaming. A Departure from $\mathrm{T}$ raining by the Book. The Boston Globe, Globe Staff. (sumber: http://bostonworks.boston.com/globe /articles/052602/elearn. html)

Purbo, O. W. (2001). Masyarakat Pengguna Internet di Indonesia. (sumber: http://www.geocities.com/inrecent/project.html).

Siahaan, S. (2001). E-Learning (Pembelajaran Elektronik) sebagai Salah Satu Alternatif Kegiatan Pembelajaran.

(sumber: http://www.depdiknas.go.id/jurnal/42/sudirman.htm) 